\title{
Does low level laser therapy relieve the pain caused by the placement of the orthodontic separators? - - a meta-analysis
}

\author{
Quan Shi, Shuo Yang, Fangfang Jia and Juan $\mathrm{Xu}^{*}$
}

\begin{abstract}
Objective: Pain caused by orthodontic treatment can affect patient's compliance and even force them to terminate treatments. The aim of this meta-analysis is to evaluate of the analgesic effect of low level laser therapy (LLLT) after placement of the orthodontic separators.

Methods: Five databases: PubMed, Embase, Cochrane library, China Biology Medicine disc (SinoMed CBM), China National Knowledge Infrastructure (CNKI) were searched for all the appropriate studies in June, 2014. Two reviewers screened the research results under our inclusion criteria and evaluated the risk of bias independently. Then the data of the included studies was extracted for quantitative analysis by the Review Manager 5.1 software.

Results: Six studies were included in our meta-analysis finally. Comparing to the placebo group, the LLLT has good analgesic effect at $6 \mathrm{~h}, 1 \mathrm{~d}, 2 \mathrm{~d}, 3 \mathrm{~d}$ after placement of separators which is of statistical significance. While at $2 \mathrm{~h}, 4 \mathrm{~d}, 5 \mathrm{~d}$ after the placement, the results tend to support LLLT, but not statistically significant.

Conclusion: Based on current included studies, LLLT can reduce the pain caused by the placement of separators effectively. However, because of the high heterogeneity, well designed RCTs are required in the future.
\end{abstract}

Keywords: Pain, Orthodontic separators, Low level laser therapy, Analgesic effect, Meta-analysis

\section{Introduction}

Pain is a subjective experience and a common clinical symptom in orthodontic patients. Research shows that as many as $95 \%$ of orthodontic patients will feel pain and $8-30 \%$ of patients discontinue treatment because of pain [1-3]. Sometimes pain can affect patient's compliance and therefore affect treatment effect. Despite the orthodontic technology has been great developed, the issue of pain has not been solved very well.

Many orthodontic operations can cause pain [2, 4-7]. As a common and necessary operation, placement of separators to create enough space for bands can cause mild to moderate pain [8]. It is generally believed that when periodontal ligament under pressure, the mediators of inflammation are released, such as prostaglandins, histamine, substance $\mathrm{P}$, which cause sensitivity to the free nerve terminations and pain or discomfort after

\footnotetext{
* Correspondence: newxj@hotmail.com

Department of Stomatology, Chinese People's Liberation Army General Hospital, 28 Fuxing Road, 100853 Beijing, China
}

placement of archwires or separators [2, 9]. In several methods currently available, the medication is thought to be the most effective [10], especially the non-steroidal anti-inflammatory drugs (NSAIDs). Some articles [1, 9-11] proved that they can relieve orthodontic pain effectively. But the medication also has its side effects which cannot be ignored: allergy and inhibiting tooth movement $[10,12]$. Therefore, the application of medication is limited.

There are no effective clinically proven non-invasive, non-pharmacological methods used to relieve the pain caused by orthodontic. But some studies showed that low level laser maybe have analgesic effect [5, 13-20]. Low level laser, or low level laser therapy(LLLT), is a new internationally accepted designation and defined as laser treatment in which the energy output is low enough so as not to cause a rise in the temperature of the treated tissue above $36.5^{\circ} \mathrm{C}$ or normal body temperature[20]. LLLT can inhibit the development of inflammation [21, 22], accelerate of bone repair [23], increase the rate of teeth movement [24]. Besides, LLLT have been used to treat 
temporal-mandibular joint disorder [25], relive the pain after teeth extraction [26].

As a non-invasive method, with no report of serious adverse effect events [10], LLLT is better than drugs in clinical application prospect. But there is still a lack of reliable evidence to prove that LLLT can effectively reduce the orthodontic pain. So the aim of this systematic review is to collect the randomized controlled trials (RCTs) or controlled clinical trials (CCTs) about LLLT relive the pain of patients after placement of separators and evaluate of the analgesic effect of LLLT.

\section{Material and methods}

The methods for this review were based on the Cochrane Handbook for Systematic Reviews of Interventions [27]. In the whole process, the studies were assessed by 2 observers independently and any disagreement will resolved by discussion. The data was analyzed by the Review Manager 5.1 software.

\section{Literature search and study selection}

The following electronic databases were searched in June 2014 without time and language restricted: PubMed, Embase, Cochrane library, China Biology Medicine disc (SinoMed CBM), China National Knowledge Infrastructure (CNKI). The search strategies of PubMed, Embase and Cochrane library were showed in Table 1.

\section{Inclusion criteria}

The following selection criteria were applied.

1. Design: the studies should be designed as RCT or controlled clinical trial (CCT), including split-mouth design.

2. Participants: patients received elastomeric separators on the premolar or molar.

3. Interventions and comparators: low level laser therapy (LLLT) vs placebo. (For some studies, there are not only these two groups, if we can filter out the data we need from the studies, we will include them either.)
4. Outcome: measurement of the pain after placing the elastomeric separators.

\section{Exclusion criteria}

The exclusion criteria were as follows:

1. In vitro study (laboratory studies and animal studies), case report or letters.

2. Study without available data can not be used by our meta-analysis.

3. The pain was caused by other operations of orthodontic instead of placing the elastomeric separators.

4. The participants had systemic disease or chronic pain or histories of neurologic and psychiatric disorders and other characteristics which will have influence on the outcome.

\section{Data extraction}

We designed a table to collect the experimental information and data which include the author, country, year of publication, design type, number of participant, measure method, the pain value and standard deviation, and so on. Then use a new table to record the parameters of the laser and the treatment regimen.

\section{Risk of bias evaluation}

Totally seven items need to be taken into consideration: (1) allocation concealment, (2) random sequence generation,(3)blinding of participants and personnel, (4) blinding of outcome assessment, (5) incomplete outcome data, (6) selective reporting, (7) other bias. The risk of bias for each item was judged as low risk, high risk, or unclear risk. The overall risk of bias for the each study was evaluated by the following criteria:

If the risk of bias is low for all the items, the study is of low risk.

If one (or more than one) of the risk of bias is high for the key items, the study is of high risk.

Table 1 Search strategy and results for T pubmed, Embase and cochranme library

\begin{tabular}{|c|c|c|}
\hline Database & Search strategy & Result \\
\hline \multirow[t]{4}{*}{ pubmed } & \#1: pain OR discomfort OR toothache & 591803 \\
\hline & \#2 :(low power laser) OR ( low level laser ) OR LLLTOR (low output laser) OR (low intensity laser) & 10881 \\
\hline & \#3: orthodontic* & 52498 \\
\hline & \#4 : \#1 AND \#2 AND \#3 & 33 \\
\hline \multirow[t]{4}{*}{ EMBASE } & \#1: pain OR discomfort OR toothache & 1054689 \\
\hline & \#2: (low power laser) OR ( low level laser ) OR LLLTOR (low output laser) OR (low intensity laser) & 19478 \\
\hline & \#3: orthodontic* & 61408 \\
\hline & \#4: \#1 AND \#2 AND \#3 & 49 \\
\hline The Cochrane library & $\# 1$ : (pain OR discomfort OR toothache) AND laser AND orthodontic* & 42 \\
\hline
\end{tabular}




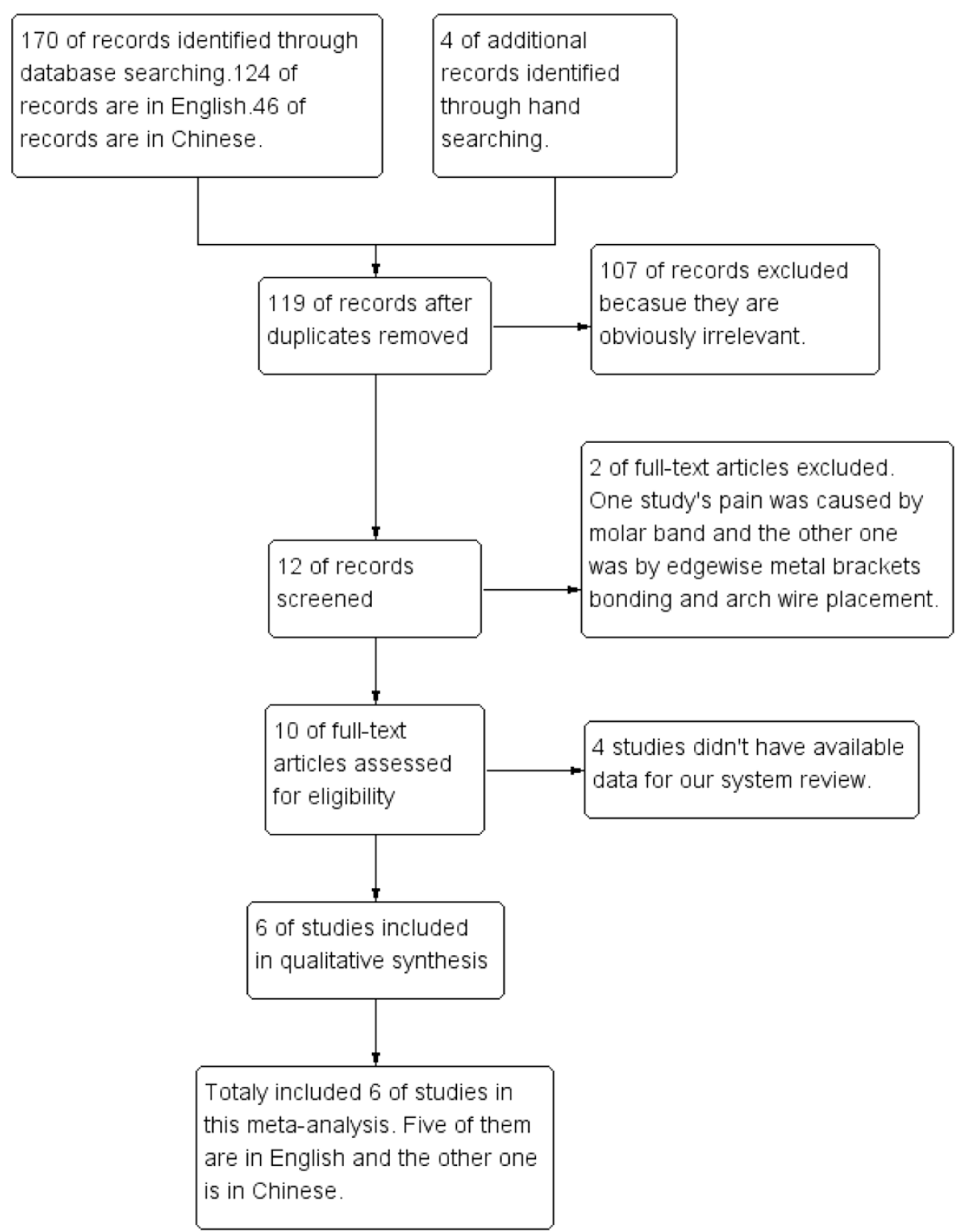

Fig. 1 Study flow diagram

Table 2 Characteristics of included studies

\begin{tabular}{llllll}
\hline Study ID & Country & Design & Number $(\mathrm{P} / \mathrm{L})^{\mathrm{a}}$ & Average age & Separators \\
\hline Celestino No'brega 2013 & Brazil & RCT & $60(30 / 30)$ & 17.5 & 3 M Unitek \\
Won Tae Kim 2012 & Korea & RCT & $58(30 / 28)$ & 21.52 & $\begin{array}{l}\text { Dentalastics Separators, Dentaurum, } \\
\text { Ispringen, Germany,2.1 mm }\end{array}$ \\
Ladan Eslamian 2013 & Iran & CCT (split mouth design) & $37(37 / 37)$ & 24.97 & Dentarum, Springen, Germany \\
Esper MA 2011 & Brazil & RCT & $38(38 / 12)$ & 23.4 & Morelli, 4.0 mm, $\varnothing 5 / 32^{\prime \prime}$ \\
Ida Marini 2013 & Italy & RCT & $80(40 / 40)$ & 23.0875 & NR $^{\text {b }}$ \\
Zhang HY 2014 & China & RCT & $60(30 / 30)$ & 15.9 & NR \\
\hline
\end{tabular}

$a_{:} P=$ placebo group; $L=L L L T$ group

${ }^{b}: \mathrm{NR}=$ not report 
Table 3 Characteristics of included studies

\begin{tabular}{|c|c|c|c|c|}
\hline Study ID & Teeth & Intervention method & Evaluation intervals & Pain measure method \\
\hline $\begin{array}{l}\text { Celestino } \\
\text { No'brega } 2013\end{array}$ & $\begin{array}{l}\text { mesial and distal sides of the } \\
\text { first permanent lower molars } \\
\text { on the left and right sides }\end{array}$ & $\begin{array}{l}\text { each subject received irradiation } \\
\text { one spot on the region of root apex, } \\
\text { three points along the root axis on } \\
\text { the buccal side }\end{array}$ & 2 h,6 h,24h,3 d,5 d & $\begin{array}{l}\text { VAS ; The incidence } \\
\text { of free of pain }\end{array}$ \\
\hline Won Tae Kim 2012 & $\begin{array}{l}\text { mesially and distally on both } \\
\text { of the maxillary first molars. }\end{array}$ & $\begin{array}{l}\text { apply laser for } 30 \text { seconds on } \\
\text { each area immediately then every } \\
12 \text { hours for } 1 \text { week with close contact } \\
\text { between the tip and mucosa to irradiate } \\
\text { the mesiobuccal, mesiolingual, distobuccal, } \\
\text { and distolingual areas. }\end{array}$ & $\begin{array}{l}5 \mathrm{~min}, 1 \mathrm{~h}, 6 \mathrm{~h}, 12 \mathrm{~h}, 1 \mathrm{~d}, \\
2 \mathrm{~d}, 3 \mathrm{~d}, 4 \mathrm{~d}, 5 \mathrm{~d}, 6 \mathrm{~d}, 7 \mathrm{~d}\end{array}$ & VAS \\
\hline $\begin{array}{l}\text { Ladan } \\
\text { Eslamian } 2013\end{array}$ & $\begin{array}{l}\text { first permanent molars } \\
\text { (distal and mesial), } \\
\text { either on maxillary } \\
\text { (22 patients) or mandibular } \\
\text { (15 patients) arches }\end{array}$ & $\begin{array}{l}\text { laser irradiation on the buccal side } \\
\text { (at the cervical third of the roots), } \\
\text { for distal and mesial of the second } \\
\text { premolars and first permanent molars, } \\
\text { as well as distal of second permanent } \\
\text { molars (five doses). The same procedure } \\
\text { was repeated for the lingual or palatal } \\
\text { side (five doses). After } 24 \mathrm{~h} \text {, patients returned } \\
\text { to the clinic and received another } 10 \text { doses } \\
\text { of laser irradiation on the same quadrant. }\end{array}$ & $\begin{array}{l}0 \mathrm{~h}, 6 \mathrm{~h}, 24 \mathrm{~h}, 30 \mathrm{~h}, \\
3 \mathrm{~d}, 4 \mathrm{~d}, 5 \mathrm{~d}, 6 \mathrm{~d}, 7 \mathrm{~d}\end{array}$ & VAS \\
\hline Esper MA 2011 & $\begin{array}{l}\text { Placebo :mesial and distal } \\
\text { of the first upper and lower } \\
\text { molar on the right side while } \\
\text { the Laser group on left side }\end{array}$ & $\begin{array}{l}\text { Radiation was applied punctually, touching } \\
\text { the gum perpendicularly on two points of } \\
\text { the vestibular side and on the lingual side of } \\
\text { the separated molars, both points were in } \\
\text { the cervical and radicular region }\end{array}$ & $\begin{array}{l}\text { pre-placement } 2 \mathrm{~h}, \\
24 \mathrm{~h}, 48 \mathrm{~h}, 72 \mathrm{~h}, 96 \mathrm{~h}\end{array}$ & VAS \\
\hline Ida Marini 2013 & $\begin{array}{l}\text { right first, second premolar } \\
\text { and first molar (upper arch } \\
\text { or lower arch) }\end{array}$ & $\begin{array}{l}\text { The laser probe was applied on the cervical } \\
\text { third of buccal and lingual gingiva I covering } \\
\text { of each root. }\end{array}$ & 0 h,12 h,24 h,36 h,48 h,72 h,96 h & VAS,Questionnaire \\
\hline Zhang HY 2014 & First molar & $\begin{array}{l}\text { the laser probe was } 5 \mathrm{~mm} \text { away from the } \\
\text { mucosal ,Laser irradiation was applied on } \\
\text { first molar root apical ,then Move up along } \\
\text { the long axis of the tooth to the tooth neck } \\
\text { (totally } 4 \text { points) }\end{array}$ & $2 h, 6 h, 24 h, 72 h, 120 h$ & VAS \\
\hline
\end{tabular}

Table 4 Detail of the lasers and parameters

\begin{tabular}{|c|c|c|c|c|c|c|c|c|}
\hline Study ID & Laser type & $\begin{array}{l}\text { Wave } \\
\text { length } \\
(\mathrm{nm})\end{array}$ & $\begin{array}{l}\text { Output } \\
\text { power } \\
(\mathrm{mW})\end{array}$ & $\begin{array}{l}\text { Number of } \\
\text { irradiated } \\
\text { points or } \\
\text { area }(\mathrm{cm} 2)\end{array}$ & Irradiation time & Frequency & Dose $(\mathrm{J} / \mathrm{cm} 2)$ & $\begin{array}{l}\text { Field } \\
\text { diameter }\end{array}$ \\
\hline $\begin{array}{l}\text { Celestino No'brega } \\
2013\end{array}$ & $\begin{array}{l}\text { aluminum } \\
\text { gallium arsenide } \\
\text { diode laser }\end{array}$ & 830 & 40.6 & 4 points & $\begin{array}{l}25 \mathrm{~s} \text { per each } \\
1 \mathrm{~J} / \mathrm{cm} 2, \\
\text { totally } 125 \mathrm{~s}\end{array}$ & $\begin{array}{l}\text { after placing } \\
\text { the separator }\end{array}$ & $\begin{array}{l}\text { root apex } \\
2 \mathrm{~J} / \mathrm{cm} 2 \text {,the other } \\
\text { three points was } \\
1 \mathrm{~J} / \mathrm{cm} 2 \text {, totally } \\
5 \mathrm{~J} / \mathrm{cm} 2\end{array}$ & $2 \mathrm{~mm}$ \\
\hline Won Tae Kim 2012 & $\begin{array}{l}\text { semiconductor } \\
\text { laser device with } \\
\text { an AlGalnP diode }\end{array}$ & 635 & 6 & 4 & $\begin{array}{l}30 \text { seconds } \\
\text { on each area }\end{array}$ & $\begin{array}{l}\text { every } 12 \mathrm{~h} \\
\text { for } 1 \text { week }\end{array}$ & $N R^{a}$ & $5.6 \mathrm{~mm}$ \\
\hline $\begin{array}{l}\text { Ladan Eslamian } \\
2013\end{array}$ & Ga-Al-As laser & 810 & 100 & 10 & $20 \mathrm{~s}$ & $\begin{array}{l}\text { laser was applied } \\
\text { immediately and } \\
24 \text { hours later after } \\
\text { placing the separators }\end{array}$ & 2 & NR \\
\hline Esper MA 2011 & InGaAIP laser & 660 & 30 & 4 & $25 \mathrm{~s}$ each point & $\begin{array}{l}\text { after placing } \\
\text { the separator }\end{array}$ & $\begin{array}{l}4 \mathrm{~J} / \mathrm{cm} 2 \text { per point, } \\
\text { totally } 16 \mathrm{~J} / \mathrm{cm} 2 \\
\text { per tooth }\end{array}$ & $5 \mathrm{~mm}$ \\
\hline Ida Marini 2013 & $\begin{array}{l}\text { GaAs diode } \\
\text { laser superpulsed } \\
\text { wave }\end{array}$ & 910 & 160 & 6 & totally $340 \mathrm{~s}$ & $\begin{array}{l}\text { The irradiation started } \\
\text { immediately after } \\
\text { placing orthodontic } \\
\text { separators. }\end{array}$ & NR & $8 \mathrm{~mm}$ \\
\hline Zhang HY 2014 & $\begin{array}{l}\text { semiconductor } \\
\text { laser }\end{array}$ & $\begin{array}{l}650 \\
\text { and } \\
830\end{array}$ & 30 & 4 & $\begin{array}{l}305 \text { each point, } \\
\text { totally } 120 \text { s per tooth }\end{array}$ & $\begin{array}{l}\text { after placing the } \\
\text { separator }\end{array}$ & NR & 3-5 mm \\
\hline
\end{tabular}




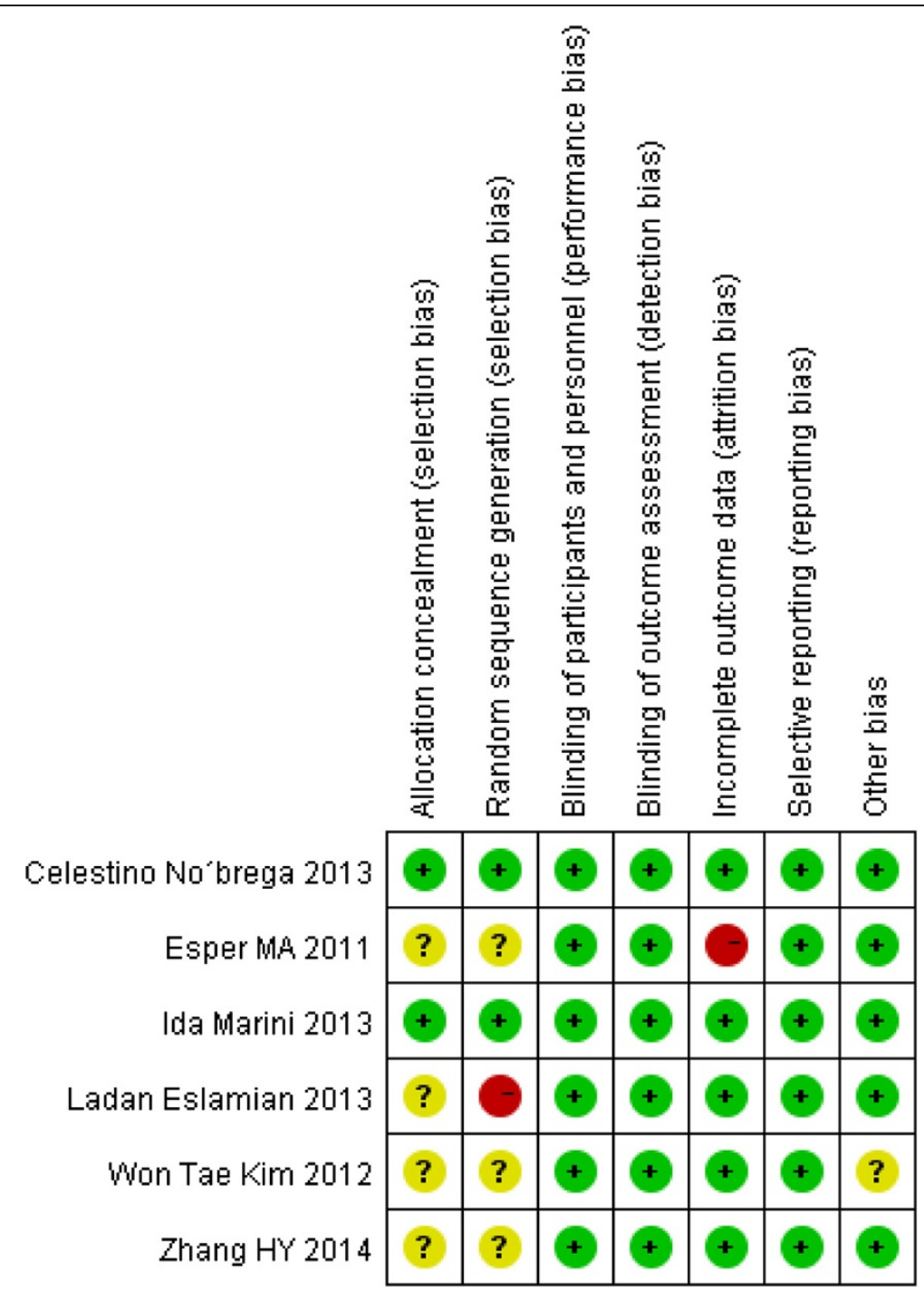

Fig. 2 Risk of bias for every study. Of the six included studies, two $[13,19]$ of them were judged to have a low risk of bias because all the items were of low risk of bias and one study [19] is a random, triple-blinding, placebo control clinic trail while the other one [13] is a random double-blinding, placebo control clinic trail. Two $[14,20]$ of the six studies were judged to have an unclear risk of bias, because the authors failed to describe the method of randomization and had no report of the allocation concealment. At the same time, the study of Won Tae Kim, et al. [14] was judged to have unclear bias on the item of "other bias" because the application of the laser was performed by the subjects at home, so there may be compliance bias. Two studies $[15,29]$ were judged to have a high risk of bias because one of the studies [15] used inappropriate method of randomization and there was a subject drop out without details description in the study of Esper MA, et al. [29]

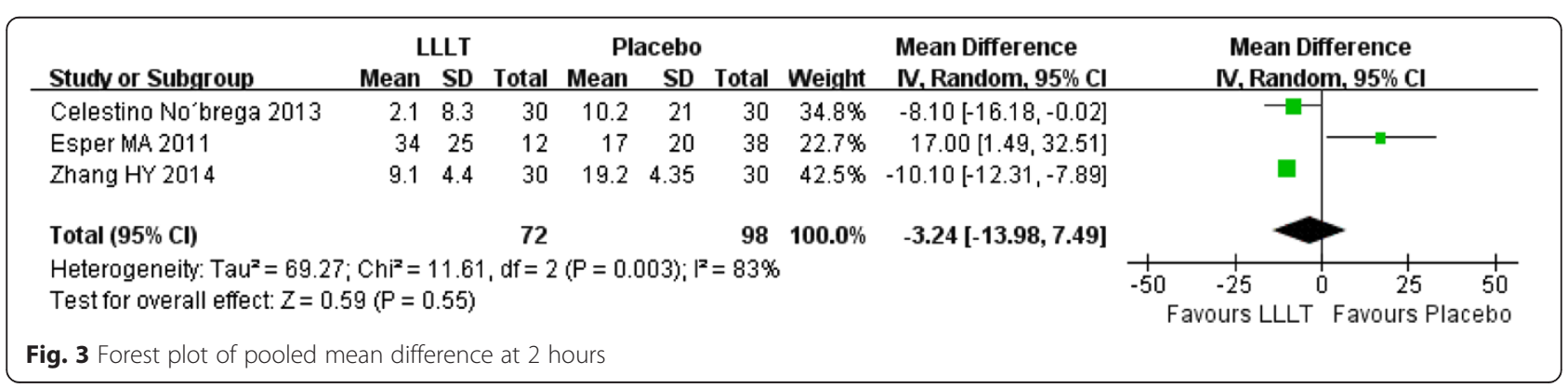




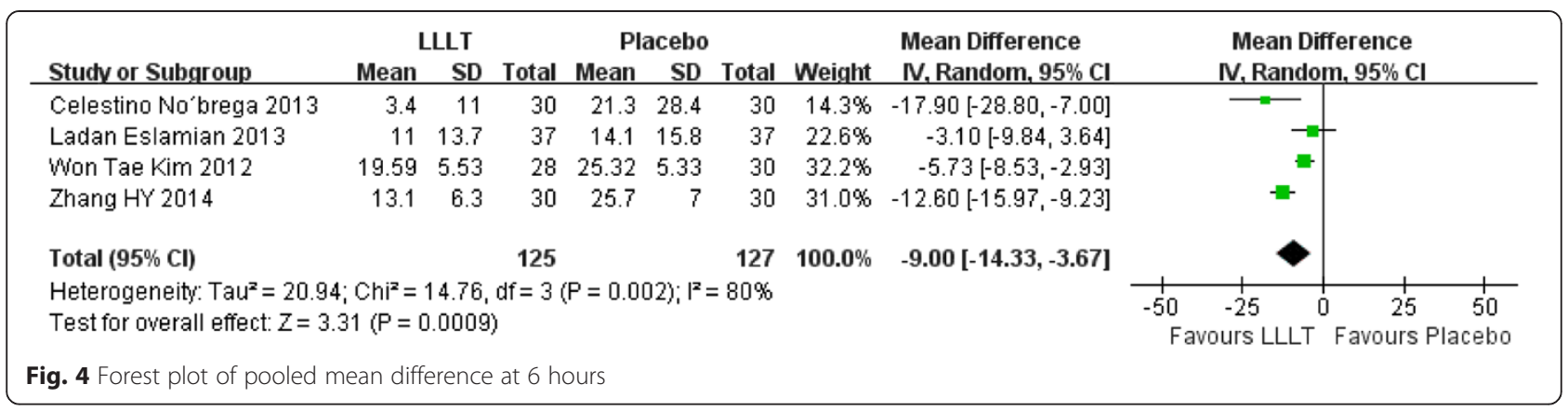

If one (or more than one) of the risk of bias is unclear, the study is of unclear risk.

\section{Data analysis}

The meta-analysis was performed by combining the results of the included studies which had measured the pain at the same evaluation intervals for the continuous data. In addition, $\mathrm{chi}^{2}$ and $\mathrm{I}^{2}$ was used to estimate the degree of heterogeneity. Mean differences, standard deviations, and $95 \%$ confidence intervals $(\mathrm{CI})$ were to be calculated for individual trials and overall effect using a random effects model or a fixed effects model for continuous data.

\section{Results}

\section{Searching and selection results}

The selection progress is shown in Fig. 1. After reading the full-text of the 10 potential interests [13-17, 19, 20, 28-30], we found that five articles [13-15, 20, 29] have available data for our meta-analysis. For the rest studies, we contacted the authors of the articles by sending e-mail (except Lim HM et al. 1995 because there is no e-mail address in the article). But only one author [19] sent us the data we needed. Finally, we include six studies [13-15, 19, 20, $29]$ in our meta-analysis. Five of them [13-15, 19, 29] are in English and the other one [20] is in Chinese.

\section{Characteristics of the included studies}

The detailed descriptions of the characteristics about the six included studies are shown in Tables 2, 3 and Table 4.
In the six studies we included, five of them are RCT $[13,14,19,20,29]$, and one is CCT [15]. Six studies encompassing 295 subjects. One study [15] used a split mouth design method. Five studies [13-15, 20, 29] placed the separator on the mesial and distal of the first molar, and one [19] placed separator on the first, second premolar and the first molar at the same time (totally four separators per subjects).

The detail of the lasers and parameters are shown in Table 4. The wavelength of the laser ranged from $635 \mathrm{~nm}$ to $910 \mathrm{~nm}$. One study [20] used a mix of $650 \mathrm{~nm}$ and $830 \mathrm{~nm}$. All the studies used a semiconductor laser. The output power ranged from $6 \mathrm{~mW}$ to $160 \mathrm{~mW}$.

All the included studies used VAS to evaluate the pain. The mean pain values and standard deviations of laser group and placebo group at each evaluation interval of the six studies are collected. In one study [19], the data was got from the author by sending e-mail. Although all of the studies used the VAS score to evaluate the pain, but the score ranged from 0 to 100 in two studies [14, 19] and the other four studies $[13,15,20,29]$ ranged from 0 to 10. However, all of them use the same method to evaluate the pain in each group. Therefore, the data of these two studies were converted to centesimal system.

\section{Risk of bias evaluation}

The risk of bias summary is shown in the Fig. 2. If there is inadequate information in the article, we will contact the author by e-mails or seek advice from statisticians. Of the

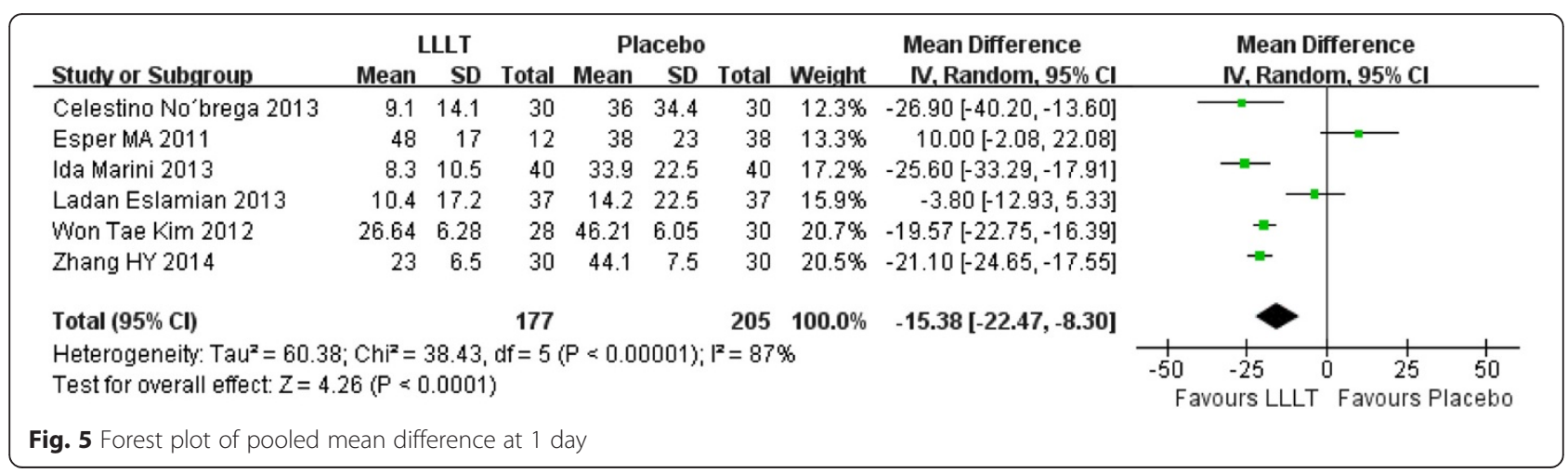




\begin{tabular}{|c|c|c|c|c|c|c|c|c|c|}
\hline Study or Subqroup & \multicolumn{2}{|c|}{ LLLT } & \multicolumn{4}{|c|}{ Placebo } & \multicolumn{2}{|r|}{ Mean Difference } & $\begin{array}{l}\text { Mean Difference } \\
\text { IV, Random, } 95 \% \mathrm{Cl}\end{array}$ \\
\hline Esper MA 2011 & 40 & 19 & 12 & 37 & 20 & 38 & $24.8 \%$ & $3.00[-9.49,15.49]$ & \\
\hline Ida Marini 2013 & 7.7 & 10.4 & 40 & 25 & 20 & 40 & $34.7 \%$ & $-17.30[-24.29,-10.31]$ & - \\
\hline Won Tae Kim 2012 & 26.59 & 6.28 & 28 & 46.09 & 6.05 & 30 & $40.5 \%$ & $-19.50[-22.68,-16.32]$ & $=$ \\
\hline Total $(95 \% \mathrm{Cl})$ & & & 80 & & & 108 & $100.0 \%$ & $-13.16[-22.81,-3.51]$ & \\
\hline \multicolumn{8}{|c|}{$\begin{array}{l}\text { Heterogeneity: } \operatorname{Tau}^{2}=57.19 ; \mathrm{Chi}^{2}=11.75, \mathrm{df}=2(\mathrm{P}=0.003) ;\left.\right|^{2}=83 \% \\
\text { Test for overall effect: } Z=2.67(P=0.008)\end{array}$} & & $\begin{array}{ccccc}-50 & -25 & 0 & 25 & 50 \\
\text { Favours LLLT } & \text { Favours Placebo }\end{array}$ \\
\hline 6 Forest plot of $\mathrm{p}$ & $d m e$ & $n$ diff & $\mathrm{ce}$ & da & & & & & \\
\hline
\end{tabular}

six included studies, two $[13,19]$ of them were judged to have a low risk of bias. Two studies $[14,20]$ were judged to have an unclear risk of bias. Two studies [15, 29] were judged to have a high risk of bias .

\section{Meta-analysis for mean score of pain}

In our included studies, if there were three or more studies measured the pain score at the same time point, we will make an analysis. Therefore, totally seven time points meet the requirements: 2 hours, 6 hours, 24 hours, 2 days, 3 days, 4 days, 5 days. Figs. 3, 4, 5, 6, 7, 8 and 9 showed the comparison between LLLT and Placebo on pain relief after placing the separators at each time point. Because of the high heterogeneity, a random effect was selected.

2 hours after the placement, the overall effect test showed no significant different between the LLLT and placebo $(\mathrm{P}=0.55)$. The mean difference was -3.24 and $95 \%$ CI $(-13.98,7.49)$ (Fig. 3).

While for the time points of $6 \mathrm{~h}, 24 \mathrm{~h}, 2 \mathrm{~d}, 3 \mathrm{~d}$, the overall effects favored the LLLT and showed a statistical difference between the LLLT and placebo, because all of the P values of the tests were less than 0.05 (Figs 4, 5, 6 and 7).

At $4^{\text {th }}$ day and $5^{\text {th }}$ day the overall effects showed there was no statistical difference between the LLLT and the placebo group $(\mathrm{P}=0.06$ at $4 \mathrm{~d}$ and $\mathrm{P}=0.15$ at $5 \mathrm{~d})$.

\section{The pain incidence}

One of the included studies reported the rate of pain never appeared and never disappeared [19]. The result showed that $30 \%$ of the LLLT group subjects did not feel pain while the placebo group was $0 \%$. In another study [13], the proportion of subjects reporting the absence of pain was significantly higher in LLLT group at each time point. Meta-analysis is not feasible because of inadequate data.

\section{Discussion}

Pain caused by orthodontic treatment can affect patient's compliance and change their eating habits [8], even forcing them to terminate treatments [13]. Orthodontists have been working on the controlling of pain. Although the NSAIDs had been proved effective on pain control, the side effects limited its clinical application [9-12]. Some researches [5, 13-20] consider LLLT as an effective method to control orthodontic pain, therefore this system review is to confirm this analgesic effect after placement of separators. Because many orthodontic operations can induce pain, in order to reduce the heterogeneity of clinical, we select the studies of using LLLT to relief pain after placing the separators.

For the orthodontic treatment with fixed appliances, the separators were used to create enough space for the bands[8]. After placement, whether separators or arch wires, the periodontal ligament and the vessels were under pressure, causing the release of inflammatory mediators and inducing pain $[2,9]$.

However, it is difficult to measure the pain precisely because pain is a subjective experience, the individual variability of pain threshold and sensitivity can be influenced by physical and psychological effects [18, 19]. Besides, other factors, such as environmental, sociocultural, genetic

\begin{tabular}{|c|c|c|c|c|c|c|c|c|c|}
\hline \multirow[b]{2}{*}{ Study or Subaroup } & \multicolumn{3}{|c|}{ LLLT } & \multicolumn{2}{|c|}{ Placebo } & \multirow[b]{2}{*}{ Total } & \multirow[b]{2}{*}{ Weight } & \multirow{2}{*}{$\begin{array}{l}\text { Mean Difference } \\
\text { IV, Random, } 95 \% \mathrm{Cl}\end{array}$} & \multirow{2}{*}{$\begin{array}{c}\text { Mean Difference } \\
\text { IV. Random, } 95 \% \mathrm{Cl}\end{array}$} \\
\hline & Mean & SD & Total & Mean & SD & & & & \\
\hline Celestino No'brega 2013 & 4.9 & 10.6 & 30 & 21 & 30.9 & 30 & $8.6 \%$ & $-16.10[-27.79,-4.41]$ & \\
\hline Esper MA 2011 & 36 & 13 & 12 & 27 & 17 & 38 & $11.5 \%$ & $9.00[-0.13,18.13]$ & \\
\hline Ida Marini 2013 & 2.2 & 2.5 & 40 & 13.9 & 4.5 & 40 & $23.5 \%$ & $-11.70[-13.30,-10.10]$ & $=$ \\
\hline Ladan Eslamian 2013 & 11.4 & 15.6 & 37 & 13.9 & 19.1 & 37 & $13.2 \%$ & $-2.50[-10.45,5.45]$ & \\
\hline Won Tae Kim 2012 & 26.4 & 6.2 & 28 & 36.78 & 5.98 & 30 & $21.5 \%$ & $-10.38[-13.52,-7.24]$ & - \\
\hline Zhang $\mathrm{HY} 2014$ & 12.8 & 5.9 & 30 & 28.3 & 6.1 & 30 & $21.6 \%$ & $-15.50[-18.54,-12.46]$ & - \\
\hline Total $(95 \% \mathrm{Cl})$ & & & 177 & & & 205 & $100.0 \%$ & $-9.02[-13.29,-4.74]$ & \\
\hline $\begin{array}{l}\text { Heterogeneity: } \operatorname{Tau}^{2}=19.5 \\
\text { Test for overall effect: } Z=4 \text {. }\end{array}$ & $\begin{array}{l}\mathrm{Chi}^{2}=3 \\
4(\mathrm{P}<0\end{array}$ & $\begin{array}{l}32.10 \\
0.0001)\end{array}$ & $d f=5$ & $P<0.00$ & $0001) ;$ & $F^{2}=84^{\circ}$ & & & $\begin{array}{ccccc} & 1 & & 1 & 1 \\
-50 & -25 & 0 & 25 & 50 \\
& \text { Favours LLLT } & \text { Favours Place bo }\end{array}$ \\
\hline
\end{tabular}




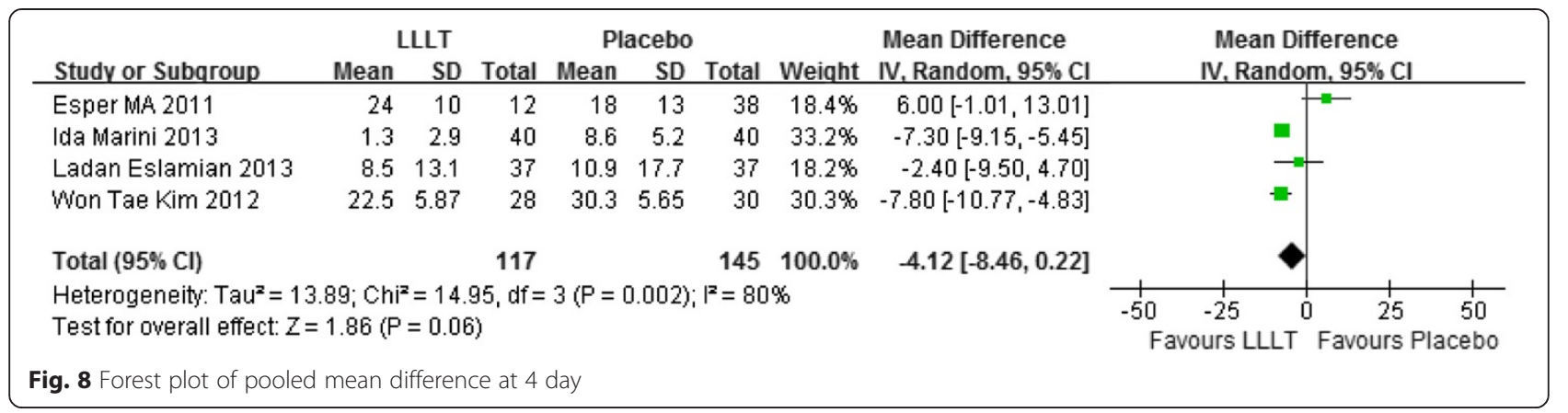

factors, and so on, can influence pain [15]. Therefore, from these viewpoints, the split-mouth design perhaps is the best choice. In our included studies, only one is splitmouth design. There are no objective measurements for pain. The VAS is one of the most common used tools to measure pain intensity at present $[8,16]$. All of the six included studies in this review used this method. What's more, in order to avoid the psychological effect, we need well designed clinical trials to evaluate the pain. Using placebo is one of our included criteria, which would increase the reliability of the results and decrease the psychological effects. Two of the six included studies used red light [19] or light-emitting diode(LED) [14] whose intensity was very low compared to the laser. The other four studies used pseudo-laser as placebo. Only two studies $[13,19]$ reported the correct random sequence generation method and allocation concealment.

In our meta-analysis, compare to the placebo group, the LLLT has good analgesic effect and the results favored the LLLT at $6 \mathrm{~h}, 1 \mathrm{~d}, 2 \mathrm{~d}, 3 \mathrm{~d}$ after placement of separators which is of statistical significance. While at $2 \mathrm{~h}, 4 \mathrm{~d}, 5 \mathrm{~d}$, the results tend to support LLLT without statistically significant. A system review [26] concluded that LLLT modulates biochemical inflammatory markers and produces local anti-inflammatory effects in cells and soft tissue which contribute to relief acute pain in the short-term. Besides, the review found there were strong evidences that LLLT can improve angiogenesis. Because of high heterogeneity of different studies which may be caused by different races, laser parameters, using methods and frequency, bias risk, we chose a random effect model. At present, the most commonly used non-surgical lasers are diode, with a wave length ranging from 600 to $1,000 \mathrm{~nm}$, and potencies between 10 and $100 \mathrm{~mW}$ [29]. The wave length of laser used in the six included studies ranged from 635-910 nm and the output power between 6 and $160 \mathrm{~mW}$. All the LLLT in the six studies used semiconductor laser. Besides, the frequency and use method were different in each study. According to some research $[5,13,15]$, the laser does not inhibit the cell activity if the dose less than $20 \mathrm{~J} / \mathrm{cm}^{2}$.The laser doses of included studies were all less than $20 \mathrm{~J} / \mathrm{cm}^{2}$. At the same time, there were no adverse effects reported by these studies using the lasers under the current parameter ranges.

Two studies $[13,19]$ report the rate of free of pain $(\mathrm{VAS}=0)$. One [19] report the rate of pain never appeared and the result showed that $30 \%$ of the LLLT group subjects did not feel pain while the placebo group was $0 \%$. In the other one study [13], the proportion of subjects reporting the absence of pain was significantly higher in LLLT group at each time point. Although it is impossible to make a meta-analysis because of clinical heterogeneity and insufficient data, their results support the effective analgesic effect of LLLT.

According to the results of our meta-analysis, LLLT can reduce the pain caused by the placement of separators effectively without adverse effect under current evidence. Considering LLLT may increase the speed of tooth

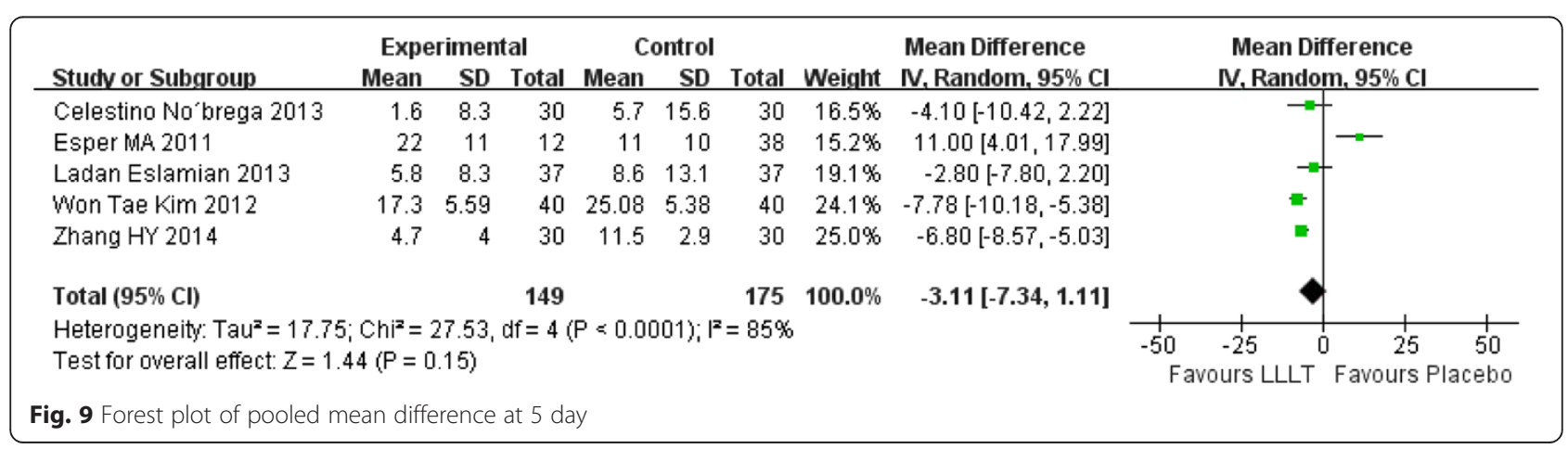


movement [22], in the field of orthodontics, LLLT may have broad application prospects. But different studies used different separators, different lasers and parameters, different method and frequency of laser, different test positions (mandible or maxilla or both), different design and different risk of bias, and these can lead to the high heterogeneity. Therefore, well designed RCTs are required to evaluate the analgesic effect of LLLT.

\section{Conclusion}

Under current studies and evidences, the results of our meta-analysis reveals that LLLT can reduce the pain caused by the placement of separators effectively at $6 \mathrm{~h}$, $1 d, 2 d, 3 d$ after the placement of the orthodontic separators without adverse effect reports. Besides, there is no evidence reveals that LLLT can bring forward the most painful day. These results indicate the good clinical application prospect. However, because of the high heterogeneity and the bias risk of included studies, well designed RCTs are required in the future.

\section{Competing interests}

This work was supported by Clinical scientific research fund (No.320.6750.15029) from Wu Jieping Medical Foundation.

\section{Authors' contributions}

SQ carried out the literature research and drafted the manuscript. The part of study selection, data extraction, risk of bias evaluation was finished by SQ and YS. For the part of data analysis, it was completed by SQ and JFF. XJ is the Corresponding author and she undertook the work of design of this meta-analysis, coordination and helped to draft the manuscript. All authors read and approved the final manuscript.

\section{Acknowledgments}

We are grateful to Dra. Maria Ângela L. R. Esper (Institute for Ortodontia e Ortopedia Especializada), Bortolotti F (Institute for Department of Neurosciences, Section of Orthodontics, University of Naples "Federico II", Italy, via Pansini), and A. Puigdollers (Department of Orthodontics and Dentofacial Orthopedics, Dental School, International University of Catalunya, Campus Sant Cugat, Josep Trueta $s / n))$, for giving us the data we need and answering our questions by E-mail.

Received: 25 May 2015 Accepted: 10 August 2015

Published online: 28 August 2015

\section{References}

1. Krishnan V. Orthodontic pain: from causes to management-a review. Eur J Orthod. 2007;29(2):170-9.

2. Bergius M, Kiliaridis S, Berggren U. Pain in orthodontics. A review and discussion of the literature. J Orofac Orthop. 2000;61(2):125-37.

3. Hoar S, Linnell KJ. Cognitive load eliminates the global perceptual bias for unlimited exposure durations. Atten Percept Psychophys. 2013;75(2):210-5.

4. Zawawi KH. Acceptance of orthodontic miniscrews as temporary anchorage devices. Patient Prefer Adherence. 2014 Jun 30:8:933-7.

5. Tortamano A, Lenzi DC, Haddad AC, Bottino MC, Dominguez GC, Vigorito JW. Low-level laser therapy for pain caused by placement of the first orthodontic archwire: a randomized clinical trial. Am J Orthod Dentofacial Orthop. 2009;136(5):662-7.

6. Youssef M, Ashkar S, Hamade E, Gutknecht N, Lampert F, Mir M. The effect of low-level laser therapy during orthodontic movement: a preliminary study. Lasers Med Sci. 2008;23(1):27-33.

7. Erdinç AM, Dinçer B. Perception of pain during orthodontic treatment with fixed appliances. Eur J Orthod. 2004;26(1):79-85.

8. Bondemark L, Fredriksson K, Iros S. Separation effect and perception of pain and discomfort from two types of orthodontic separators. World J Orthod. 2004;5(2):172-6.
9. Polat O, Karaman Al. Pain control during fixed orthodontic appliance therapy. Angle Orthod. 2005;75(2):214-9.

10. Xiaoting $L$, Yin $T$, Yangxi $C$. Interventions for pain during fixed orthodontic appliance therapy. A systematic review. Angle Orthod. 2010;80(5):925-32.

11. Salmassian R, Oesterle L, Shellhart WC, Newman SM. Comparison of the efficacy of ibuprofen and acetaminophen in controlling pain after orthodontic tooth movement. Am J Orthod Dentofacial Orthop. 2009;135(4):516-21.

12. Kyrkanides S, O'Banion MK, Subtelny JD. Nonsteroidal anti-inflammatory drugs in orthodontic tooth movement: metalloproteinase activity and collagen synthesis by endothelial cells. Am J Orthod Dentofacial Orthop. 2000;118(2):203-9.

13. Nóbrega C, da Silva EM, de Macedo CR. Low-level laser therapy for treatment of pain associated with orthodontic elastomeric separator placement: a placebocontrolled randomized double-blind clinical trial. Photomed Laser Surg. 2013;31(1):10-6.

14. Kim WT, Bayome M, Park JB, Park JH, Baek SH, Kook YA. Effect of frequent laser irradiation on orthodontic pain. A single-blind randomized clinical trial. Angle Orthod. 2013;83(4):611-6.

15. Eslamian L, Borzabadi-Farahani A, Hassanzadeh-Azhiri A, Badiee MR, Fekrazad R. The effect of 810-nm low-level laser therapy on pain caused by orthodontic elastomeric separators. Lasers Med Sci. 2014;29(2):559-64

16. Artés-Ribas M, Arnabat-Dominguez J, Puigdollers A. Analgesic effect of a low-level laser therapy $(830 \mathrm{~nm})$ in early orthodontic treatment. Lasers Med Sci. 2013;28(1):335-41.

17. Fujiyama K, Deguchi T, Murakami T, Fujii A, Kushima K, Takano-Yamamoto T. Clinical effect of $\mathrm{CO}_{2}$ laser in reducing pain in orthodontics. Angle Orthod. 2008:78(2):299-303.

18. He WL, Li CJ, Liu ZP, Sun JF, Hu ZA, Yin X, et al. Efficacy of low-level laser therapy in the management of orthodontic pain: a systematic review and meta-analysis. Lasers Med Sci. 2013;28(6):1581-9.

19. Marini I, Bartolucci ML, Bortolotti F, Innocenti G, Gatto MR, Alessandri Bonetti G. The effect of diode superpulsed low-level laser therapy on experimental orthodontic pain caused by elastomeric separators: a randomized controlled clinical trial. Lasers Med Sci. 2013. [Epub ahead of print]

20. Zhang HY, Yan Y, Deng HY, Liu HX. Clinical therapeutic evaluation of low-level laser in alleviating pain during orthodontic elastomeric separator placement. Journal of Chinese Practical Diagnosis and Therapy. 2014;28(3):256-8.

21. Saygun I, Karacay S, Serdar M, Ural AU, Sencimen M, Kurtis B. Effects of laser irradiation on the release of basic fibroblast growth factor (bFGF), insulin like growth factor-1 (IGF-1), and receptor of IGF-1 (IGFBP3) from gingival fibroblasts. Lasers Med Sci. 2008;23(2):211-5.

22. Pallotta RC, Bjordal JM, Frigo L, Leal Junior EC, Teixeira S, Marcos RL, et al. Infrared (810-nm) low-level laser therapy on rat experimental knee inflammation. Lasers Med Sci. 2012;27(1):71-8.

23. Pinheiro AL, Gerbi ME. Photoengineering of bone repair processes. Photomed Laser Surg. 2006;24(2):169-78.

24. Sousa MV, Scanavini MA, Sannomiya EK, Velasco LG, Angelieri F. Influence of low-level laser on the speed of orthodontic movement. Photomed Laser Surg. 2011;29(3):191-6.

25. Fikácková H, Dostálová T, Navrátil L, Klaschka J. Effectiveness of low-level laser therapy in temporomandibular joint disorders: a placebo-controlled study. Photomed Laser Surg. 2007;25(4):297-303.

26. Bjordal JM, Johnson MI, Iversen V, Aimbire F, Lopes-Martins RA. Low-level laser therapy in acute pain: a systematic review of possible mechanisms of action and clinical effects in randomized placebo-controlled trials. Photomed Laser Surg. 2006;24(2):158-68.

27. Higgins JPT, Green S, editors. Cochrane handbook for systematic reviews of interventions [version 5.1.0]. The Cochrane Collaboration. 2011.

28. Lim HM, Lew KK, Tay DK. A clinical investigation of the efficacy of low level laser therapy in reducing orthodontic postadjustment pain. Am J Orthod Dentofacial Orthop. 1995;108(6):614-22.

29. Esper MA, Nicolau RA, Arisawa EA. The effect of two phototherapy protocols on pain control in orthodontic procedure-a preliminary clinical study. Lasers Med Sci. 2011;26(5):657-63.

30. Abtahi SM, Mousavi SA, Shafaee H, Tanbakuchi B. Effect of low-level laser therapy on dental pain induced by separator force in orthodontic treatment. Dent Res J (Isfahan). 2013;10(5):647-51. 